\title{
Impact of sperm DNA damage and oocyte-repairing capacity on trout development
}

\author{
C Fernández-Díez, S González-Rojo, M Lombó and M P Herráez \\ Department of Molecular Biology, Faculty of Biology, University of León, León, Spain \\ Correspondence should be addressed to M P Herráez; Email: paz.herraez@unileon.es
}

\begin{abstract}
Zygotic repair of paternal DNA is essential during embryo development. In spite of the interest devoted to sperm DNA damage, its combined effect with defect-repairing oocytes has not been analyzed. Modification of the breeding season is a common practice in aquaculture. This practice reduces developmental success and could affect the both factors: sperm DNA integrity and oocyte repair capacity. To evaluate the maternal role, we analyzed the progeny outcome after fertilizing in-season trout oocytes with untreated and with UV-irradiated sperm. We also analyzed the offspring obtained out of season with untreated sperm. The analysis of the number of lesions in 4 sperm nuclear genes revealed an increase of 1.22-11.18 lesions/10 kb in out-of-season sperm, similar to that obtained after sperm UV irradiation $\left(400 \mu \mathrm{W} / \mathrm{cm}^{2} 5 \mathrm{~min}\right)$. Gene expression showed in out-of-season oocytes the overexpression of repair genes (ogg1, ung, lig3, rad1) and downregulation of tp53, indicating an enhanced repairing activity and reduced capacity to arrest development upon damage. The analysis of the progeny in out-of-season embryos revealed a similar profile tolerant to DNA damage, leading to a much lower apoptotic activity at organogenesis, lower hatching rates and increased rate of malformations. The effects were milder in descendants from in-season-irradiated sperm, showing an enhanced repairing activity at epibolia. Results point out the importance of the repairing machinery provided by the oocyte and show how susceptible it is to environmental changes. Transcripts related to DNA damage signalization and repair could be used as markers of oocyte quality.

Reproduction (2016) 152 57-67
\end{abstract}

\section{Introduction}

DNA integrity of germinal cells is a crucial factor allowing the proper transmission of parental genetic information to the progeny (Santos et al. 2013, Marchetti et al. 2015). During spermatogenesis, particularly in meiotic steps, DNA is very prone to suffer lesions. Moreover, spermatic chromatin is very sensitive to environmental stress generated by factors, such as UV irradiation, thermal changes, presence of chemicals, that could increase oxidative stress or affect the DNA compaction mechanisms (Shamsi et al. 2011). In addition, the DNA repair ability of male germ cells is high during mitotic and meiotic phases, but is lost in postmeiotic spermatids with the reduction of the cytoplasmic content and the compaction of the nuclei, which limits the access of the DNA repair machinery (Baarends et al. 2001, Marchetti et al. 2015). Chromatin stability is better preserved on the oocytes. Female gametes, are prone to accumulating errors related to the process of correct chromosome segregation (Caroll et al. 2013), and may be susceptible to damage by reactive oxygen species (ROS) (Menezo et al. 2010). Nevertheless, they have a fully active machinery leading to repair genomic lesions promoted during oogenesis (Kurus et al. 2013).
It has been repeatedly demonstrated both in mammals and in fish that fertilization capacity can be preserved in spermatozoa showing standard quality in terms of motility and morphology although carrying a damaged genome (Upadhya et al. 2010, Avendano \& Oehninger 2011, Perez-Cerezales et al. 2011, Fernandez-Diez et al. 2015). Fertilization with DNA-damaged sperm increases the risk of promoting pregnancy loss in mammals (Speyer et al. 2010), arrest in embryo development or embryo death (Perez-Cerezales et al. 2010b, Gawecka et al. 2013), birth defects, chromosomal abnormalities and other genetic diseases (Fernandez-Gonzalez et al. 2008, Barroso et al. 2009, Schulte et al. 2010, Marchetti et al. 2015). The DNA-repairing activity relies on the oocyte machinery once the fertilization takes place (Aitken et al. 2014, Fernandez-Diez et al. 2015), the zygote being responsible for repairing the sperm damage. In previous studies, we found that trout oocytes are able to repair at least $10 \%$ of sperm DNA fragmentation (Perez-Cerezales et al. 2010) and demonstrated that the suppression of the repairing activity in trout zygotes, using an inhibitor of the Poli (ADP-ribose) polymerase (PARP) activity involved in the base excision repair (BER) pathway, has severe consequences for the progeny: alternative repairing mechanisms were activated, embryo survival was reduced and surviving larvae displayed massive 
differences in the transcriptomic profile (Fernandez-Diez et al. 2015). The zygote repairing ability is thus a key factor guarantying the progress of a proper development, mainly when paternal DNA integrity is compromised. Nevertheless, the effects of different intrinsic and extrinsic factors on the oocyte, from genetic background to ageing (Hamatani et al. 2004), cryopreservation, in vitro culture or environmental clues, could also affect the repairing activity of the zygote. Therefore, those factors potentially harmful for male and female gametes could have synergic effects with a serious impact on the conceptus development, compromising the long-term outcome of the progeny.

Fish have been used as models in the study of the effects of sperm DNA damage on the reproductive success given the advantage provided by its high prolificacy (allowing the study of a high number of descendants from the same mating), easy process of artificial fertilization and weak mechanism of sperm selection (facilitating fertilization with damaged spermatozoa) and external development (giving free access to embryos throughout development) (Kopeika et al. 2004, Perez-Cerezales et al. 2009, 2010b, 2011, Fernandez-Diez et al. 2015).

Most fish species from temperate areas are seasonal breeders, but reproduction out of season is easily induced in many commercial species by environmental or hormonal stimulation. Among salmonids - breeding in cold water - photoperiod manipulation is usually applied in order to obtain an all-year-round production (Billard \& Reinaud 1978). Nevertheless, due to the mismatch between the artificial photoperiod and temperature regimes in warmer periods of the year, overall oocyte quality, embryonic survival and larval performance are usually lower in the out-of-the-natural-breeding period (Bobe \& Labbe 2010, Migaud et al. 2013). An increase of DNA sperm damage (Perez-Cerezales et al. 2010a) and defective vitellogenesis in oocytes (Bobe \& Labbe 2010) that could affect embryo development have been identified in out-of-season breeders, but the oocyterepairing activity and it's combined effect with the sperm chromatin integrity have never been explored.

The hypothesis is that warmer temperature during gametogenesis in out-of-season breeders, apart from affecting sperm DNA integrity, could modify the oocyte-repairing activity, compromising the offspring development at short and long term. DNA-repair-related transcripts and lesions in DNA will be analyzed in oocytes and sperm respectively, both during optimal breeding season (ORS) (from breeders maintained with natural photoperiod) and at a later period (LRS) (from breeders under artificial photoperiod and warmer temperature regimes). The offspring development will be evaluated at decisive stages during embryo development up to hatching. The ability to progress with development when sperm genotoxic damage is promoted by UV irradiation will also be assessed at ORS.

\section{Materials and methods}

\section{Reagents}

All media components were purchased from Sigma-Aldrich except when otherwise stated.

\section{Experimental procedures}

The experiments were carried out in accordance with the Guidelines of the European Union Council (86/609/EU, modified by 2010/62/EU), following Spanish regulations (RD 1201/2005, abrogated by RD 53/2013) for the use of laboratory animals, and were approved by the Committee on the Ethics of Animal Experiments of the University of León (Permit Number: 15-2011). Animals were killed using the concussion method by qualified personal and all efforts were made to minimize suffering.

\section{Sperm and eggs collection}

Sperm was obtained from sex-reversed ripe rainbow trout (Oncorhynchus mykiss) females (neomales), which were maintained under artificial photoperiod in a fish farm (Lugo, Spain). Neomales from two different batches were killed, four from a batch breeding during ORS (December-January) and five from a batch breeding at LRS (February-March). The testicles were dissected and blood vessels were removed. Sperm was extracted directly from testicle after making several incisions with a scalpel. Sperm was diluted 1:10 in a commercial maturation medium, Storfish (IMV, L'aigle, France) and samples were kept $2 \mathrm{~h}$ at $4{ }^{\circ} \mathrm{C}$ with oxygenation before processing. Eggs were obtained by abdominal massage from two different females in each collection time. After checking their proper quality by visual inspection, the eggs were pooled and divided in batches for fertilization procedures.

\section{Sperm UV irradiation}

Sperm from each male from ORS, obtained in season, was divided in two aliquots, one of them was used as control and the other one was subjected to UV-C irradiation. Before irradiation, sperm was diluted 1:3 with SFMM (Seminal Fluid Mimicking Medium) (110 mM NaCl, $28.18 \mathrm{mM} \mathrm{KCl}, 1.22 \mathrm{mM}$ $\mathrm{MgSO}_{4} \cdot 7 \mathrm{H}_{2} \mathrm{O}, 1.77 \mathrm{mM} \mathrm{CaCl} \cdot 2 \mathrm{H}_{2} \mathrm{O}, 10.05 \mathrm{mM}$ bicine, $9.9 \mathrm{mM}$ HEPES, $\mathrm{pH}$ 7.4). Twenty $\mathrm{mL}$ of diluted sperm were transferred to a Petri dish, $10 \mathrm{~cm}$ diameter, giving a thin layer of sperm. The Petri dish was located $15 \mathrm{~cm}$ under a UV lamp (Vilber Lourmat, Eberhardzell, Germany) (254 nm) receiving $400 \mu \mathrm{W} / \mathrm{cm}^{2}$ irradiation for $5 \mathrm{~min}$. Then, treated and control samples were kept in darkness at $4^{\circ} \mathrm{C}$ until further analysis.

\section{Fertilization and embryo incubation}

Pooled eggs were divided into 26 batches with 400 eggs/batch and 2 batches per treatment. They were fertilized with fresh sperm or irradiated sperm from each neomale separately, both of them diluted 1:3 with SFMM, as previously stated (2 replicates/treatment) (Fig. 1). One milliliter of sperm was added over the eggs and stirred with a feather. After $10 \mathrm{~min}$ 


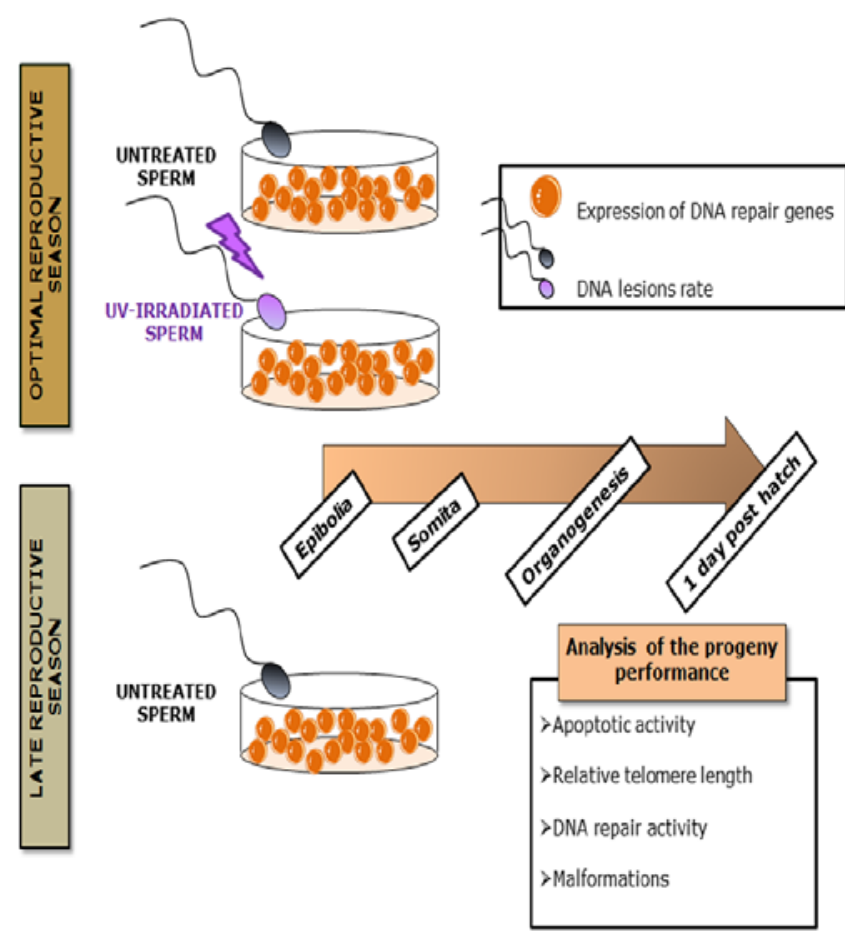

Figure 1 Scheme of the experimental design.

of incubation, the sperm was activated with $10 \mathrm{~mL}$ of DIA solution $(94.97 \mathrm{mM} \mathrm{NaCl}, 49.95 \mathrm{mM}$, Glycine, $19.98 \mathrm{mM}$ Tris, $\mathrm{pH}$ 7.4). Ten minutes later, the eggs were washed with water and incubated in the darkness at $10^{\circ} \mathrm{C}$ with a continuous water flow of $24 \mathrm{~L} / \mathrm{min}$ until hatching.

Fifteen embryos from each replicate were collected at different developmental stages following the classification of Vernier (Vernier 1969) stage 13 (epibolia), stage 19 (somita), stage 23 (organogenesis) and stage 30 (larvae 1 day post hatch $(1 \mathrm{dph})$ ). The embryos were cleared with a solution containing $50 \mathrm{~mL}$ formaldehyde, $40 \mathrm{~mL}$ acetic acid and $60 \mathrm{~mL}$ glycerine to check the proper development and identify the aborted embryos. Ten additional embryos at each stage per treatment were frozen at $-80^{\circ} \mathrm{C}$ for DNA and RNA extraction and ten more for the analysis of the apoptotic activity. During development, all the aborted embryos were removed and, after hatching, the hatching rates and cumulative percentage of abortions were calculated.

\section{Genomic DNA extraction}

Total genomic DNA was extracted from untreated and irradiated sperm following the protocol described by CartónGarcía et al. (2013). For late embryos (stages 13 and 23) and larvae (stage 30), a digestion step with $6 \mathrm{mg} / \mathrm{mL}$ collagenase in PBS $1 \times$ during $2 \mathrm{~h}$ at $37^{\circ} \mathrm{C}$ was carried out. To stop the reaction, the cells were washed with two volumes of PBS $1 \times$ and the pellet was resuspended in $700 \mu \mathrm{L}$ of extraction buffer $(10 \mathrm{mM}$ Tris- $\mathrm{HCl}$, pH 8.0; $100 \mathrm{mM}$ EDTA, pH 8.0; 0.5\% (v/v) SDS, supplemented with $1 \mu \mathrm{L}$ proteinase $\mathrm{K}(1 \mathrm{mg} / \mathrm{mL}))$. DNA quantity and purity were determined spectrophotometrically at $260 \mathrm{~nm}$ (Nanodrop ND-1000 Spectrophotometer, Thermo
Scientific). All samples showed high yield (A260/A280>1.8), and were stored at $-20^{\circ} \mathrm{C}$ until further processing.

\section{RNA extraction and reverse transcription}

Total RNA from embryos at 13th, 23th and larvae $1 \mathrm{dph}$ stages and from 20 unfertilized eggs collected at two different moments of the reproductive season was extracted using the Trizol Regeant Kit (Applied Biosystems) following the manufacturer's instructions. RNA integrity was confirmed by electrophoresis analysis of total RNA samples before reverse transcription (data not shown). Total RNA concentration was determined using a NanoDrop ND-1000 Spectrophotometer (Thermo Scientific). About $1 \mu \mathrm{g}$ of total RNA from embryos, larvae and eggs was reverse transcribed using the High Capacity cDNA Kit (Applied Biosystems) following the manufacturer's instructions. The conditions applied for reverse transcription were $25^{\circ} \mathrm{C}$ for $10 \mathrm{~min}, 37^{\circ} \mathrm{C}$ for $120 \mathrm{~min}$ and final extension at $85^{\circ} \mathrm{C}$ for $5 \mathrm{~min}$. RT-qPCR was performed using a Step-One Plus thermocycler (Applied Biosystems). Complementary DNA products were kept at $-20^{\circ} \mathrm{C}$ until further analysis.

\section{DNA lesion rate in sperm}

The RT-qPCR approach described by Rothfuss et al. (2010) was applied to analyze the number of lesion in four nuclear genes previously studied in rainbow trout by GonzalezRojo et al. (2014): hoxc4a-2, eifib, sox2 and 185 rRNA. For each gene, two genomic DNA fragments of different length in the same region were amplified: long fragments with up to $700 \mathrm{bp}$ and short ones with less than $100 \mathrm{bp}$. Reaction mix for the long amplicons contained $4 \mu \mathrm{L}$ Fast Start DNA Master plus SYBR Green I (Roche), $0.4 \mu \mathrm{L} 50 \times$ ROX passive reference dye (Bio-Rad), 3 ng of genomic DNA and $0.5 \mu \mathrm{L}$ of each $10 \mu \mathrm{M}$ forward and reverse primer. RT-qPCR started with a pre-incubation of $95^{\circ} \mathrm{C}$ for $10 \mathrm{~min}$ followed by 40 cycles of $95^{\circ} \mathrm{C}$ for $15 \mathrm{~s}$, annealing temperature specific for each couple of primers for $10 \mathrm{~s}$ and $72{ }^{\circ} \mathrm{C}$ for $50 \mathrm{~s}$. For short fragments reaction mixture contained $10 \mu \mathrm{L} 2 \times \mathrm{SYBR}$ Green PCR Master Mix (Applied Biosystems), $0.5 \mu \mathrm{L}$ of each $10 \mu \mathrm{M}$ forward and reverse primer and $3 \mathrm{ng}$ of genomic DNA. RT-qPCR began with a pre-incubation of $95^{\circ} \mathrm{C}$ for $10 \mathrm{~min}$ followed by 40 cycles of $95^{\circ} \mathrm{C}$ for $15 \mathrm{~s}$, annealing temperature for $1 \mathrm{~min}$. Three technical replicates were performed per sample. The RT-qPCR conditions were optimized for the different primers to achieve similar amplification efficiencies. Product specificity was tested by melting curves and product size was visualized using agarose gel electrophoresis (data not shown). The nucleotide sequences and GenBank accession numbers are given in Table 1.

The differences of $\mathrm{Ct}$ values between irradiated sperm samples and untreated sperm samples for each long and short fragments were calculated according the formula described by Rothfuss et al. (2010).

$$
\text { Lesion rate }=1-2^{-(\Delta C \text { tlong }-\Delta C \text { tshort })} \times \frac{10,000(\mathrm{bp})}{\text { size of long fragment }(\mathrm{bp})}
$$


Table 1 Oligonucleotide sequences of the PCR primers used to assay the DNA lesions by RT-qPCR.

\begin{tabular}{|c|c|c|c|c|}
\hline Primer name & Primer set $\left(5^{\prime}-3^{\prime}\right)$ & Amplicon size (bp) & Annealing $\operatorname{Tm}\left({ }^{\circ} \mathrm{C}\right)$ & Accesion number \\
\hline hoxc4a-2 (long) & $\begin{array}{l}\text { F: AACAGCTACATCCCCGACCACAG } \\
\text { R: TCGCGCACATAGGCTACATAACAG }\end{array}$ & 643 & 65 & AY567804 \\
\hline hoxc4a-2 (short) & $\begin{array}{l}\text { F:GTGCCTCTAACTCCCATCTCC } \\
\text { R:CAAAAGCTTCTCCCCTATCGT }\end{array}$ & 57 & 63 & \\
\hline eif1b (long) & $\begin{array}{l}\text { F:CCCAGAGTATGGGGAAGTGA } \\
\text { R: GTTGGTAGCCCAGCATCAAT }\end{array}$ & 634 & 63 & NM_001165193 \\
\hline eif1b (short) & $\begin{array}{l}\text { F: GGCTGCATACGTCCATGTTA } \\
\text { R:GGCTGCGATGATCAGAACTT }\end{array}$ & 56 & 63 & \\
\hline sox2 (long) & $\begin{array}{l}\text { F:AGTTGTCAAGGCTCTGGCGA } \\
\text { R: GCCTCCСССТАСАСССАСT }\end{array}$ & 651 & 65 & NM_001141718 \\
\hline sox2 (short) & $\begin{array}{l}\text { F:ATGGGTTCGGTGGTCAAGTC } \\
\text { R:GGAGTGAGACGACGACGTGA }\end{array}$ & 66 & 63 & \\
\hline rRNA $18 S$ (long) & $\begin{array}{l}\text { F:CCGCAGCTAGGAATAATGGA } \\
\text { R:CTCAATCTCGTGTGGCTGAA }\end{array}$ & 632 & 65 & FJ710873 \\
\hline rRNA $18 S$ (short) & $\begin{array}{l}\text { F:ATGGCCGTTCTTAGTTGGTG } \\
\text { R: CCGGAGTCTCGTTCGTTATC }\end{array}$ & 63 & 63 & \\
\hline
\end{tabular}

For DNA lesion rate analysis, untreated samples from ORS were used as reference. For each nuclear gene, the difference in the Ct values (long fragment/short fragment) was used as a measure of relative DNA lesion frequency with the $2^{-\Delta \Delta C t}$ method (Livak \& Schmittgen 2001) in relation to the amplification size of the long fragment.

\section{Evaluation of DNA-repair-related transcripts in the oocytes}

Reverse transcribed products from RNA extracted from twenty unfertilized oocytes obtained in both breeding seasons (ORS and LRS) were used to perform a RT-qPCR assay. Five genes implied in at least one DNA repair pathway or DNA damage checkpoint were tested: ung (Uracil-DNA-Glicosylase) and ogg1 (8-oxoguanine DNA glycosilase) involved in BER pathway, lig3 (ligase 3) implied in both excision repair pathways (BER and NER), tp53 (tumor protein P53) regulating different genes involved in DNA repair, cell cycle and apoptosis, and rad1 (DNA repair exonuclease) regulating the cell cycle progress in response to DNA damage.

cDNA products were diluted $1: 3$ in nuclease-free water and $2 \mu \mathrm{L}$ was used for each RT-qPCR. The primers were designed using Primer Express (Software v2.0, Applied Biosystems) and Primer Select (Software v10.1 DNA Star, Lasergene Core Suit). The primer nucleotide sequences and annealing temperature from rainbow trout repair genes are provided in Table 2 . The RT-qPCR conditions were optimized for the different primers to achieve similar amplification efficiencies. Product specificity was checked by melting curves and product size was visualized by electrophoresis on agarose gel (data not shown).

Reaction mixtures (total volume $20 \mu \mathrm{L}$ ) contained $2 \mu \mathrm{L}$ of cDNA, $10 \mu \mathrm{L}$ of $1 \times$ SYBR Green Master mix (Applied Biosystems) and $0.5 \mu \mathrm{L}$ of $10 \mu \mathrm{M}$ each forward and reverse primer. RT-qPCR was initiated with a pre-incubation phase of $10 \mathrm{~min}$ at $95^{\circ} \mathrm{C}$ followed by 40 cycles of $95^{\circ} \mathrm{C}$ denaturation for $10 \mathrm{~s}$ and $1 \mathrm{~min}$ of specific annealing temperature of each primer. Three technical replicates were performed per sample. Expression level for each repair gene was normalized to $18 \mathrm{~S}$ RNA gene using the delta-Ct $(2 \Delta \mathrm{Ct})$ method.

\section{Analysis of the progeny performance}

Parameters were checked in all the progenies obtained at epibolia, somita, organogenesis and larvae 1 dph stages.

\section{Apoptotic activity}

Quantitative apoptotic activity was analyzed using ten alive embryos/larvae per treatment. They were anaesthetized with MS-222 (80 mg/L), following the protocol described by Fernandez-Diez et al. (2015) including a previous step of dechorionization for embryos at stage 13 at 23. Embryos and larvae cut in small pieces and fragments were incubated $3 \mathrm{~h}$ under agitation in a dissociation solution containing $3.6 \%(\mathrm{w} / \mathrm{v})$ trypsine, $2.4 \mathrm{~mL}$ DNAse I (Applied Biosystems) and $10 \%(\mathrm{v} / \mathrm{v}) \mathrm{FBS}$ in Leibovitz's (L-15) medium. Embryos

Table 2 Oligonucleotide sequences of the PCR primers used to assay the repair activity by RT-qPCR.

\begin{tabular}{|c|c|c|c|c|}
\hline Primer name & Primer set $\left(5^{\prime}-3^{\prime}\right)$ & Amplicon size (bp) & Annealing $\operatorname{Tm}\left({ }^{\circ} \mathrm{C}\right)$ & Accesion number \\
\hline ung & $\begin{array}{l}\text { F:TGTCTACCCACССССТСAGCA } \\
\text { R:CCGTGATATGGGTCCTGGCCG }\end{array}$ & 96 & 63 & ВT048282.2 \\
\hline $\operatorname{ogg} 1$ & $\begin{array}{l}\mathrm{F}: G G C G G G C A A T G G G C A G A A G A \\
\text { R:CCGAGTGTGCCCAACCAGCA }\end{array}$ & 101 & 64 & NM_001140547.1 \\
\hline lig3 & $\begin{array}{l}\text { F:TGGTGCGATTTTGAAGTGTG } \\
\text { R:GGTCCTGTGTCCTTGTGGTT }\end{array}$ & 147 & 64 & ВТ043957.1 \\
\hline tp53 & $\begin{array}{l}\mathrm{F}: G G T C A G A G T T G A G G G G A A C \\
\text { R:GTGTCTCCAGGGTGATG }\end{array}$ & 197 & 60 & NM_001124692.1 \\
\hline rad1 & $\begin{array}{l}\mathrm{F}: G G A G C T G T T T C A G T G C A C \\
\text { R:CGAAGCAGATCTGTCCATC }\end{array}$ & 170 & 63 & JX310656.1 \\
\hline
\end{tabular}


Table 3 Oligonucleotide sequences of the PCR primers used to assay the telomere length by RT-qPCR.

\begin{tabular}{lll}
\hline Primer name & Primer set $\left(\mathbf{5}^{\prime} \mathbf{-} \mathbf{3}^{\prime}\right.$ ) & Source \\
\hline Telomere & F:CGGTTTGTTTGGGTTTGGGTTTGGGTTTGGGTTTGGGTT & Fernández-Díez et al. (2015) \\
rRNA $18 \mathrm{R}:$ SGCTTGCCTTACCCTTACCCTTACCCTTACCCTTACCCT & F:ATGGCCGTTCTTAGTTGGTG & González-Rojo et al. (2015) \\
& R: CCGGAGTCTCGTTCGTTATC & \\
\hline
\end{tabular}

at epibolia stage were kept in the dissociation solution for $1 \mathrm{~h}$. The embryo and larvae fragments were gently and repeatedly pipetted to facilitate the dissociation process. Then, cells were filtered using a $140 \mathrm{~mm}$ nylon mesh and washed twice with a solution containing L-15 medium. The activity of caspases 3/7 was analyzed using the Caspase-Glo 3/7 Assay Systems Kit (Promega) following the instructions of the manufacturer.

\section{Relative telomere length}

Telomere length was measured by RT-qPCR assay using telomeric primers and genomic DNA. Reaction mix (total volume $20 \mu \mathrm{L}$ ) for each sample contained $0.03 \mu \mathrm{g}$ of genomic DNA, $10 \mu \mathrm{L}$ of Quantimix easy SYBR kit (Biotools, Madrid, Spain), $0.4 \mu \mathrm{L}$ of $50 \times$ ROX passive reference dye (Bio-Rad) and $0.5 \mu \mathrm{L}$ of $10 \mu \mathrm{M}$ each forward and reverse primer. RT-qPCR began with a pre-incubation of $94^{\circ} \mathrm{C}$ for $3 \mathrm{~min}$ and $40 \mathrm{cycles}$ of $94^{\circ} \mathrm{C}$ of denaturation for $10 \mathrm{~s}, 56^{\circ} \mathrm{C}$ of annealing for $15 \mathrm{~s}$, and two extension steps of $72^{\circ} \mathrm{C}$ for $10 \mathrm{~s}$ and $78^{\circ} \mathrm{C}$ for $15 \mathrm{~s}$. Three technical replicates were carried out per sample. Telomeric signal was normalized dividing by the signal of $18 \mathrm{~S}$ rDNA as reference gene (Table 3 ). The average of this ratio compared with control embryo/larvae or control sperm was reported as relative telomere length.

\section{Offspring DNA repair activity}

DNA repair activity was evaluated by analyzing the presence of specific transcripts in embryos at 13th, 23th and larvae $1 \mathrm{dph}$ stages following the same procedure described above for unfertilized oocytes.

\section{Malformations}

One day after hatching, the malformation rate was analyzed in each progeny, classifying the malformed larvae in five types: axial axis malformed (AAM), half hatching $(\mathrm{HH})$ and yolk-sac malformed (YSM), cyclopodia (C) and prognathism (P).

\section{Statistical analysis}

Data analysis was carried out using the computerized package generated by SPSS 21.0 software for Windows (IBM, EEUU). The results were expressed as mean \pm S.E.M. One-way ANOVA test followed by the DMS or Games Howell post hoc test $(P<0.05)$ was used to analyze parametric data corresponding with cumulative percentage of abortions, hatching and growth rates, total malformations and telomere length. A non-parametric Kruskal-Wallis test was used to analyze the apoptosis and repair activity data in the progeny. Significant differences in oocyte gene expression and in the number of sperm DNA lesions were validated by an unpaired $t$-test followed by the Welch's correction using GraphPad Prism v5.0 Software (San Diego, CA, USA; $P$ value $<0.05$ ).

\section{Results}

\section{Genotoxic damage in sperm}

Results show that UV-C-irradiated sperm and sperm collected at LRS have a higher number of lesions than untreated sperm samples obtained at ORS (DecemberJanuary; Fig. 2A and B). This increase has a similar range in both types of samples (average number of lesions 4.25 in UV-irradiated sperm and 3.8 in LRS sperm). Irradiation promotes a homogeneous damage in the analyzed genes, whereas higher differences among genes were observed in LRS sperm.

\section{Gamete quality}

\section{DNA lesion rate}
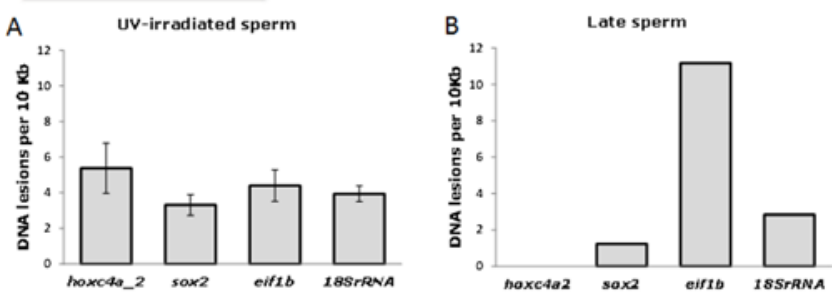

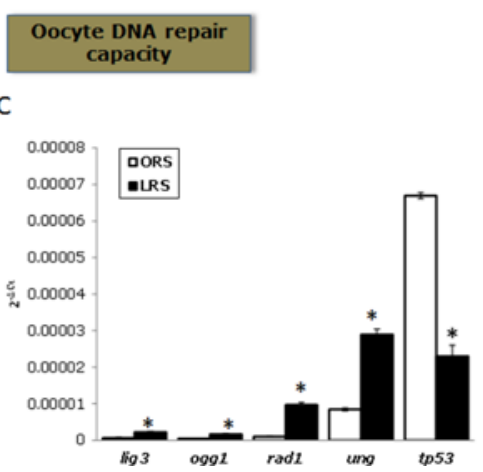

Figure 2 Rate of lesions in sperm DNA (A, B) and oocyte repairing capacity. (A) DNA damage of sperm treated with UV-C irradiation $\left(400 \mu \mathrm{W} / \mathrm{cm}^{2}\right.$ during $5 \mathrm{~min}$ ) respect to untreated sperm at ORS. Data show mean \pm S.E.M. $(n=4)$. (B) Mean DNA damage obtained from out-of-season sperm (LRS) $(n=5)$ with respect to that from on-season sperm. (C) mRNA levels (fold change $2^{\wedge C t}$ ) for lig3, ogg 1 , rad1, ung and tp53 in oocytes from different reproductive periods. Data show mean \pm S.E.M. $(n=20)$. Asterisks show significant differences between samples $(P<0.05)$. ORS, optimal reproductive season (DecemberJanuary); LRS, late reproductive season (February-March). 


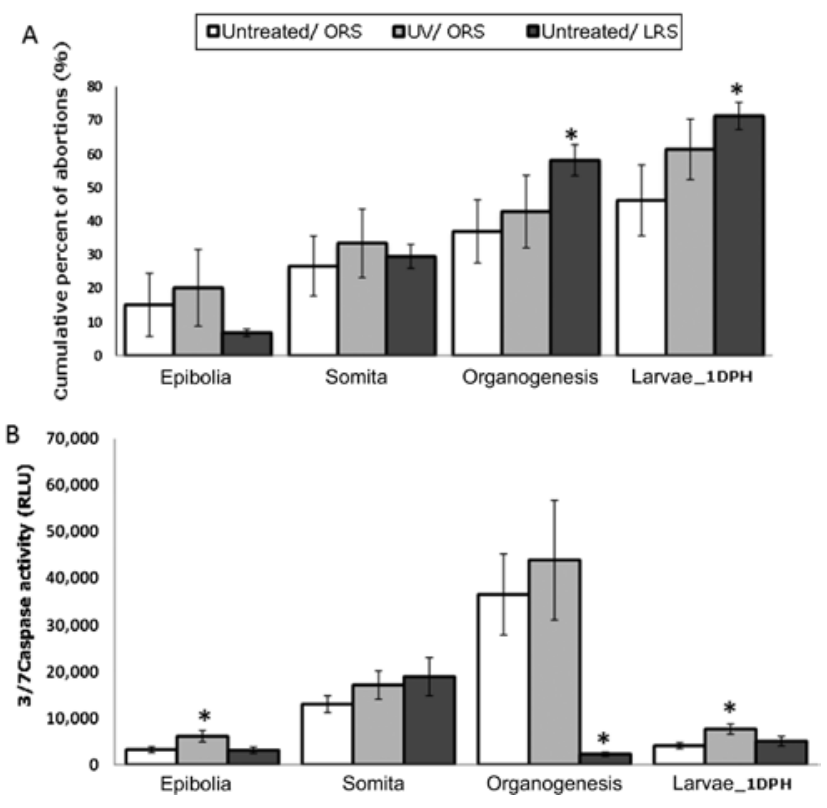

Figure 3 (A) Cumulative percentage of abortions and (B) caspase 3/7 activity in relative luminescence units (RLU) at epibolia, somita, organogenesis and larvae (1dph) stages from progenies obtained in and out of season (ORS and LRS respectively) with untreated sperm (UNTREATED) and UV-C-irradiated sperm (UV); data show mean \pm S.E.M. ( 2 batches per treatment, 400 eggs per batch for the abortions rate, and 5 embryos per batch for caspase 3/7 activity). Asterisks indicate significant differences respect to the untreated samples at ORS $(P<0.05)$.

\section{Oocyte DNA repair ability}

The expression of genes related to DNA repair (lig3, ogg 1, rad1, ung and tp53) showed significant differences among the oocytes obtained at different reproductive periods. All the analyzed transcripts, except tp53, were significantly overexpressed in LRS oocytes. lig3, ogg 1 and ung genes increased their expression about 3.5 times and rad1 as much as 9.15 times. In the case of tp53, the level of expression at ORS was higher (2.9 times) than in oocytes from females maturating at later time (Fig. 2C).

\section{Performance of the progeny}

As shown in Fig. 3A, UV irradiation of the sperm did not increase the abortion rates during embryo development. Nevertheless, a significant increase of embryo loses was noticed in batches fertilized during LRS that resulted in a lower survival at hatching $(53.83 \pm 10.54$ and 29.68 \pm 3.46 for control batches at ORS and LRS respectively).

The quantitative analysis of the caspases activity (Fig. 3B) revealed that apoptosis increases during embryo development reaching organogenesis at the highest level, and dropping at hatching. The same pattern is observed in batches fertilized with UV-damaged sperm which show higher activity than control batches at epibolia and $1 \mathrm{dph}$. Apoptotic activity displays a different pattern in LRS batches in which the level of caspase 3/7 activity did not increase at organogenesis.

The percentage of malformed larvae 1 dph was higher in batches obtained at LRS than at optimal period $(4.31 \pm 1.27$ and $11.59 \pm 0.53$ from ORS and LRS respectively) (Fig. 4B). The obtained progenies developed different types of malformations as shown in Fig. 4A. The malformations related to the axial axis formation were the most common among larvae, the higher percentage in ORS batches being from control sperm (Fig. 4C). A high percentage of embryos showing defective hatching was recorded in batches fertilized at LRS (45\%) (Fig. 4E). Prognathism was only identified in batches from
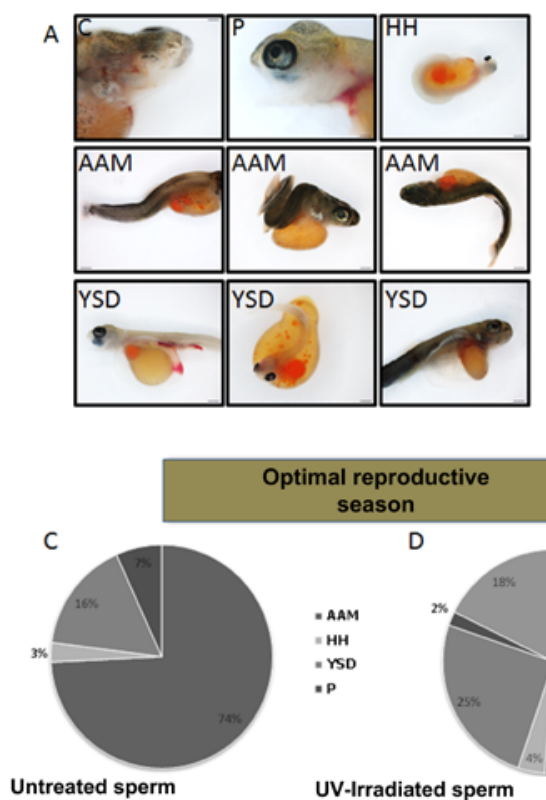

Optimal reproductive season
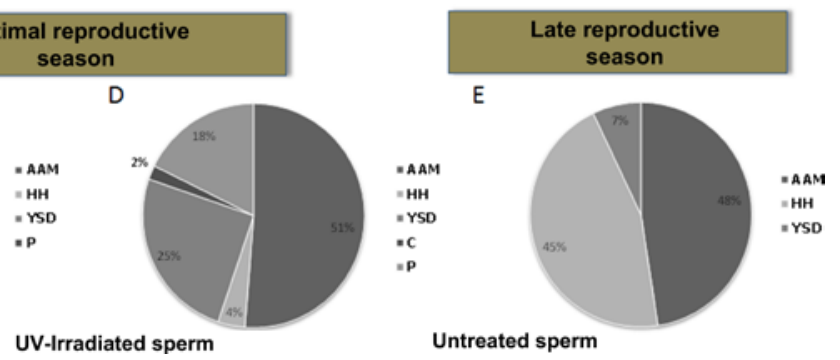

Figure 4 Phenotype analysis of larvae $1 \mathrm{dph}$ in batches obtained in and out of season (ORS and LRS respectively) with untreated sperm (UNTREATED) and UV-C-irradiated sperm (UV). (A) Types of malformations observed in larvae. $C$, cyclopodya; $P$, prognathism; $H H$, half hatching; AAM-F, axial axis malformed; YSD, yolk-sac defects. (B) Percentage of total observed malformations. (C, D and $\mathrm{E}$ ) Percentage of specific malformations. Data show mean \pm S.E.M. Asterisks indicate significant differences respect to the untreated samples at ORS $(P<0.05)(2$ batches per treatment, 400 eggs per batch). 


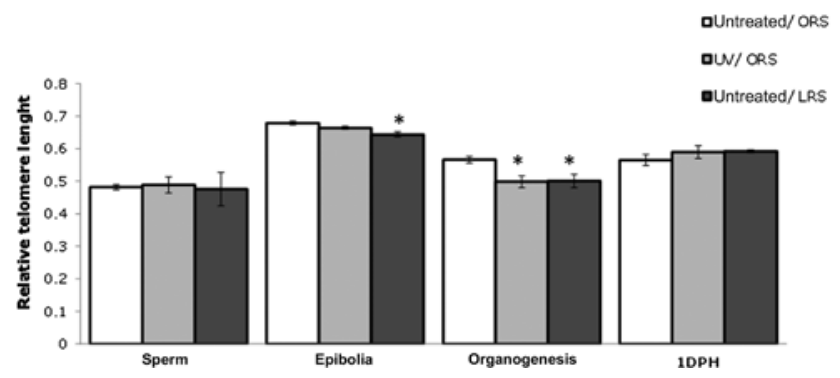

Figure 5 Relative telomere length in sperm and embryos at epibolia, organogenesis and larvae (1 dph) stages from progenies obtained in and out of season (ORS and LRS respectively) with untreated sperm (Untreated) and UV-C-irradiated sperm (UV). Asterisks indicate significant differences respect to the untreated samples at ORS $(P<0.05)(n=4$ for samples obtained at ORS and $n=5$ for samples obtained at LRS).

ORS (18\% in UV-irradiated sperm) (Fig. 4C). Larvae from UV-irradiated sperm displayed the higher percentage of yolk-sac-defective larvae (25\%) (Fig. 4C), cyclopodia only being observed in these batches.

As shown in Fig. 5, telomere length changed during embryo development. The shorter telomeres were found in sperm samples, which did not show differences between treatments, whereas progenies at epibolia stage showed the longer telomeres. Shorter telomeres in relation to the control were observed in batches from UV-irradiated sperm at epibolia and in LRS batches at epibolia and organogenesis. At hatching the telomere length was similar in all the analyzed progenies.

Gene expression analysis revealed a significantly modified profile in LRS batches at epibolia, with overexpression of genes related with DNA repair pathways BER and NER (ogg1, ung and lig3) (Fig. 6A, $\mathrm{B}$ and $\mathrm{C}$ ) and rad1 expression (Fig. 6D) and a lower expression level of tp53 (Fig. 6E). At the same stage UV-irradiated progenies showed overexpression of rad1 with respect to the ORS control. One day post hatch, the expression of tp53 was significantly higher in UV-irradiated batches and lower in late progenies than in those obtained at the optimal period.

\section{Discussion}

The proper embryo development largely relies on the integrity of the genomic information provided to the zygote. Physiological conditions during gametogenesis are crucial to ensure that the lesions promoted during recombination at meiosis or during chromatin condensation at spermiogenesis, do not exceed the species' natural repairing ability. It is well known that thermal stress has detrimental effect on spermatogenesis. Different studies show that increased temperature entails an increase of DNA fragmentation in the sperm, both in mammals (Durairajanayagam et al. 2015) and fish (Lahnsteiner \& Leitner 2013). The RT-qPCR analysis of DNA lesion showed an increase of DNA damage (up to 11 DNA lesions/10 kb) in rainbow trout sperm samples collected at LRS, breeding at higher temperatures than those from the optimal period. Similar results were observed when DNA fragmentation was analyzed using the Comet assay at the end of the natural reproductive period in rainbow trout (Perez-Cerezales et al. 2010a) or in sole Solea senegalensis breeding out of season (Beirao et al. 2011), revealing that in fish an inadequate environment promotes DNA chromatin susceptibility, as was also demonstrated in human (Takata et al. 2013). The loss of DNA integrity is commonly considered a result of failing sperm chromatin packaging during spermatogenesis, defective apoptosis and excessive ROS production (Shamsi et al. 2011, Durairajanayagam et al. 2015) and should generate an increased repairing effort upon fertilization. Nevertheless, environmental stress could also imply defective repairing mechanisms in the zygote, the maternal contribution being essential in this respect.

It is known that UV exposure increases the formation of ROS through the endogenous photosensitizers (Zan-Bar et al. 2005, Kim et al. 2015) promoting genotoxic stress. UV-C irradiation at the tested doses $\left(400 \mu \mathrm{W} / \mathrm{cm}^{2}\right)$ increased in the ORS sperm the number of DNA lesion in a range similar to those promoted by out-of-season breeding. Doses higher than the one

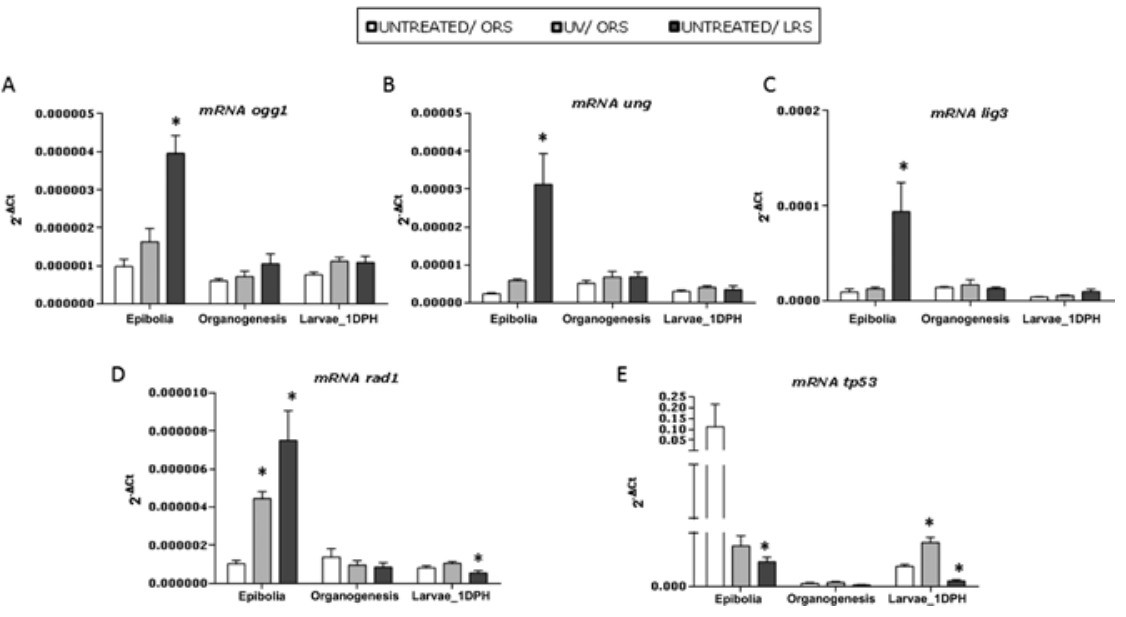

Figure 6 mRNA levels $\left(2^{\Delta \mathrm{Ct}}\right)$ for $\mathrm{rad} 1$, ogg, ung, tp53 and lig3 at different stages during development from embryos obtained in and out of season (ORS and LRS respectively) from fresh sperm (UNTREATED) and UV-C-irradiated sperm (UV). Asterisks indicate significant differences respect to the untreated samples at ORS $(P<0.05) .(n=4$ for embryos obtained at ORS and $n=5$ for embryos obtained at LRS). 
used in our study are commonly used in aquaculture to inactivate the sperm genome for gynogenetic procedures (Lin \& Dabrowski 1998, Ciereszko et al. 2005, Dietrich et al. 2005).

As demonstrated in a variety of vertebrates, unrepaired DNA lesions from paternal origin promote a slower paternal DNA replication (Gawecka et al. 2013), de novo mutations propagated to the next generation, such as hereditary diseases (Carroll \& Marangos 2013), chromosomal structural aberrations (Marchetti et al. 2015) and even lead to arrest in embryo development (Gawecka et al. 2013). As has been demonstrated in human and mouse, zygotic DNA repair initially depends on the oocyte-born mRNAs and proteins and, additionally, on genes expressed very early in development (Derijck et al. 2008, Jaroudi et al. 2009). Therefore, the combined effect of sperm DNA damage and the capacity of the oocyte to repair it will determine the final impact on the offspring development (GonzalezMarin et al. 2012).

In our study, the genotoxic treatment applied to the sperm had transitional consequences for the offspring development. Ciereszcko and colleagues (2005) observed in trout a decrease in the survival rate from 2-cell stage to pre-hatch stage on the progeny obtained with UV-C irradiated sperm with higher doses (up to $1720 \mathrm{~J} / \mathrm{m}^{2}$ ). Our results did not reveal an increase in either the accumulative abortions or in the hatching rates with respect to the control batches of the same reproductive period, revealing that ORS oocytes have the ability to properly repair the sperm lesions. Similar results were reported by Perez-Cerezales et al. (2010), who estimated that trout oocytes are able to repair sperm with a $10 \%$ fragmented chromatin. Genomic instability promoted by UV had effects early in development: an increased apoptotic activity and overexpression of rad1 were observed at epibolia, revealing the activation of mechanisms protecting from genotoxic damage. Moreover, telomere length was reduced at organogenesis. The shortening of telomeres has been previously described in human cells as a result of the erroneous repair of the pyrimidinepyrimidone (6-4) photoproducts (6-4 PPs) (Stout \& Blasco 2013) which are generated by UV irradiation in the DNA strand (reviewed by Batista et al. 2009). Sperm DNA damage seems to be identified and safely repaired early during development. Different results were obtained when the fertilized oocytes displayed an altered repairing profile. We have observed that oocytes collected out of season showed a significant increase in all the analyzed repair transcripts (up to 9.15 times in rad1mRNA) except in tp53 mRNA which was downregulated. The analyzed transcripts are involved in DNA damage control and the repair of different kind of lesions could be promoted during gametogenesis: ogg 1 is involved in the removal of 8-oxoguanyne, mutagenic base produced after ROS (Gagne et al. 2013); DNA lig3 plays a crucial role in the repairing of DNA single-strand breaks during embryo development and cannot be replaced by any other DNA ligase (Puebla-Osorio et al. 2006); ung gene encodes for uracil-DNA glycosylase which is involved in excision of uracil residues from $\mathrm{U}: \mathrm{G}$ and $\mathrm{U}: \mathrm{A}$ mispairs in DNA molecule, participating in BER pathway - recent reports in zebrafish have demonstrated its implication in a correct embryo development during post-fertilization (Wu et al. 2014); rad1 mRNA encodes Rad1, checkpoint protein which is involved in cell cycle arrest (Bozdarov et al. 2013), playing an important role during the correct embryo development (Han et al. 2010); and tp53 is one of the most important transcriptional factors with suppressive and proapoptotic functions upon genotoxic stress (Storer \& Zon 2010). The expression of tp53 is usually enhanced under conditions of genomic instability. Nevertheless, in fish cells diverse responses have been reported. Some researchers noticed induction of tp53 expresion and some other failed to detect any increase after UV irradiation, treatment with hydroxyurea or with chemotherapeutic agents with effect on mammalian cells (Liu et al. 2011). The overexpression of repairing genes that we have observed in oocytes at LRS is compatible with a higher repairing effort, required to repair the genomic lesions promoted during oogenesis in suboptimal conditions (Harrouk et al. 2000). The increased expression of rad1, also involved in the telomere-length maintenance (Khair et al. 2010), is a common surveillance mechanism activated in trout in response to genotoxic stress such as UV light or ionizing radiation (Bozdarov et al. 2013), whereas the downregulation of tp53 generates a more tolerant environment to genotoxic stress. In such conditions the zygote shows a modified repairing profile that should face the damaged male pronuclei.

The development of the batches fertilized in the two analyzed periods showed significant differences. With respect to the natural season, batches from LRS showed at epibolia the same repairing profile than oocytes: overexpression of all the analyzed transcripts and downregulation of tp53, revealing an intense repairing activity but a reduced capacity to arrest the development upon damage. Tolerance to damage, suppressing the induction of apoptosis, is a known mechanism allowing to progress with development in stressful environmental conditions, as was observed in corals (Tchernov et al. 2011) or in rainbow trout embryos with inhibited repairing machinery (Fernandez-Diez et al. 2015). tp53 in fish is very similar to mammalian TP53, and is highly and ubiquitously expressed in zebrafish early embryos (Storer \& Zon 2010). As reviewed by Liu and colleagues (2011), fish tp53 is functionally similar to mammalian TP53, being regulated by MDM2 and regulating the transcription of the same genes that drive to apoptosis. Zebrafish knockdown for tp53 is developmentally normal in homeostatic conditions, but displays a reduced induction of apoptosis after genotoxic damage (Duffy \& 
Wickstrom 2007, Storer \& Zon 2010). This effect was observed in a late stage, at organogenesis, the apoptotic activity being clearly reduced in LRS batches. Apoptosis is a key event during organogenesis allowing the bulk remodeling suffered by the embryo tissues that drive to a cascade of morphogenetic events required for the proper organ development. All the embryos obtained at the optimal season undergo a very significant increase of apoptosis which is not observed in the late embryos. This is in agreement with the downregulation of tp53 observed in the late oocytes, and probably promotes developmental failures that entail the observed increase in embryo death later on, the abortions rate increasing very significantly. Moreover, shorter telomeres are observed at epibolia and organogenesis in the LRS embryos. The percentage of hatching is lower than in ORS, whereas the percentage of malformations increases, the half hatching $(\mathrm{HH})$ being the most relevant. These malformed larvae died shortly after hatching, indicating an excess of genomic instability accumulated during embryo development which is not compatible with life. The surviving larvae still showed a lower level of tp53 at $1 \mathrm{dph}$, revealing potential risks of accumulations of genetic damage at later times. Different reports have already showed that artificial photoperiod in rainbow trout entails lower survival of embryos at eyeing stage and increased incidence of deformities (Bobe \& Labbe 2010), but our results showed how the oocyte repairing capacity is involved in the defective development. All the results showed that out-of-season breeding affects the oocyte DNA signalization and repair profile, generating an increased repairing activity in the offspring and a lower ability to induce apoptosis. Therefore, the reproductive performance is reduced: developmental failures are accumulated, promoting embryo death and decreasing the hatching rates. In addition, the rate of malformed larvae is increased.

Our results have shown the synergic effects of sperm DNA damage and oocyte repairing ability on embryo development, pointing out the importance of the repairing machinery provided to the zygote and showing how susceptible it is to environmental stress. The differential expression of DNA damage surveillance and repair genes in the oocyte deeply affect the embryo development, promoting defective apoptosis and impaired embryo development that entails lower hatching rates and higher larvae malformation rates. The presence of specific transcript representatives for the capacity of DNA damage signalization and repair could be used as markers of oocyte quality.

\section{Declaration of interest}

The authors declare that there is no conflict of interest that could be perceived as prejudicing the impartiality of the review.

\section{Funding}

This work was supported by the Spanish Ministry of Economy and Competitiveness (project AGL2011-27787).

\section{Acknowledgements}

Authors acknowledge the contribution of Ignacio Prusén Mota and Emeline Moureaux.

\section{References}

Aitken RJ, Smith TB, Jobling MS, Baker MA \& De Iuliis GN 2014 Oxidative stress and male reproductive health. Asian Journal of Andrology 16 31-38. (doi:10.4103/1008-682X.122203)

Avendano C \& Oehninger S 2011 DNA fragmentation in morphologically normal spermatozoa: how much should we be concerned in the ICSI era? Journal of Andrology 32 356-363. (doi:10.2164/ jandrol.110.012005)

Baarends WM, van der Laan R \& Grootegoed JA 2001 DNA repair mechanisms and gametogenesis. Reproduction 12131-39. (doi:10.1530/ rep.0.1210031)

Barroso G, Valdespin C, Vega E, Kershenovich R, Avila R, Avendano C \& Oehninger S 2009 Developmental sperm contributions: fertilization and beyond. Fertility and Sterility 92 835-848. (doi:10.1016/ j.fertnstert.2009.06.030)

Batista LF, Kaina B, Meneghini R \& Menck CF 2009 How DNA lesions are turned into powerful killing structures: insights from UVinduced apoptosis. Mutation Research 681 197-208. (doi:10.1016/ j.mrrev.2008.09.001)

Beirao J, Soares F, Herraez MP, Dinis MT \& Cabrita E 2011 Changes in Solea senegalensis sperm quality throughout the year. Animal Reproduction Science 126 122-129. (doi:10.1016/j.anireprosci.2011.04.009)

Billard R \& Reinaud P 1978 Testicular feed back on the hypothalamopituitary axis in rainbow trout (Salmo gairdneri R.). Annales de Biologie Animale, Biochimie, Biophysique 18 813-818. (doi:10.1051/ rnd:19780509)

Bobe J \& Labbe C 2010 Egg and sperm quality in fish. General and Comparative Endocrinology 165 535-548. (doi:10.1016/ j.ygcen.2009.02.011)

Bozdarov J, Sherry JP, Duncker BP, Bols NC \& Dixon B 2013 The rad1 gene in Rainbow Trout (Oncorhynchus mykiss) is highly conserved and may express proteins from non-canonical spliced isoforms. Comparative Biochemistry and Physiology Part C: Toxicology \& Pharmacology 157 16-23. (doi:10.1016/j.cbpc.2012.09.002)

Carroll J \& Marangos P 2013 The DNA damage response in mammalian oocytes. Frontiers in Genetics 4 117. (doi:10.3389/fgene.2013.00117)

Cartón-García F, Riesco M, Cabrita E, Herráez MP \& Robles V 2013 Quantification of lesions in nuclear and mitochondrial genes of Sparus aurata cryopreserved sperm. Aquaculture 402-403 106-112. (doi:10.1016/j.aquaculture.2013.03.034)

Ciereszko A, Wolfe TD \& Dabrowski K 2005 Analysis of DNA damage in sea lamprey (Petromyzon marinus) spermatozoa by UV, hydrogen peroxide, and the toxicant bisazir. Aquatic Toxicology 73 128-138. (doi:10.1016/j.aquatox.2005.03.003)

Derijck A, van der Heijden G, Giele M, Philippens M \& de Boer P 2008 DNA double-strand break repair in parental chromatin of mouse zygotes, the first cell cycle as an origin of de novo mutation. Human Molecular Genetics 17 1922-1937. (doi:10.1093/hmg/ddn090)

Dietrich GJ, Szpyrka A, Wojtczak M, Dobosz S, Goryczko K, Zakowski L \& Ciereszko A 2005 Effects of UV irradiation and hydrogen peroxide on DNA fragmentation, motility and fertilizing ability of rainbow trout (Oncorhynchus mykiss) spermatozoa. Theriogenology 64 1809-1822. (doi:10.1016/j.theriogenology.2005.04.010)

Duffy KT \& Wickstrom E 2007 Zebrafish tp53 knockdown extends the survival of irradiated zebrafish embryos more effectively than the p53 inhibitor pifithrin-alpha. Cancer Biology \& Therapy 6 675-678. (doi:10.4161/cbt.6.5.3956) 
Durairajanayagam D, Agarwal A \& Ong C 2015 Causes, effects and molecular mechanisms of testicular heat stress. Reproductive Biomedicine Online 30 14-27. (doi:10.1016/j.rbmo.2014.09.018)

Fernandez-Diez C, Gonzalez-Rojo S, Montfort J, Le Cam A, Bobe J, Robles V, Perez-Cerezales S \& Herraez MP 2015 Inhibition of zygotic DNA repair: transcriptome analysis of the offspring in trout (Oncorhynchus mykiss). Reproduction 149 101-111. (doi:10.1530/REP14-0382)

Fernandez-Gonzalez R, Moreira PN, Perez-Crespo M, Sanchez-Martin M, Ramirez MA, Pericuesta E, Bilbao A, Bermejo-Alvarez P, de Dios Hourcade J, de Fonseca FR et al. 2008 Long-term effects of mouse intracytoplasmic sperm injection with DNA-fragmented sperm on health and behavior of adult offspring. Biology of Reproduction 78 761-772. (doi:10.1095/biolreprod.107.065623)

Gagne F, Andre C, Turcotte P, Gagnon C, Sherry J \& Talbot A 2013 A comparative toxicogenomic investigation of oil sand water and processed water in rainbow trout hepatocytes. Archives of Environmental Contamination and Toxicology 65 309-323. (doi:10.1007/s00244-0139888-2)

Gawecka JE, Marh J, Ortega M, Yamauchi Y, Ward MA \& Ward WS 2013 Mouse zygotes respond to severe sperm DNA damage by delaying paternal DNA replication and embryonic development. PLOS ONE 8 e56385. (doi:10.1371/journal.pone.0056385)

Gonzalez-Marin C, Gosalvez J \& Roy R 2012 Types, causes, detection and repair of DNA fragmentation in animal and human sperm cells. International Journal of Molecular Sciences 13 14026-14052. (doi:10.3390/ijms131114026)

Gonzalez-Rojo S, Fernandez-Diez C, Guerra SM, Robles V \& Herraez MP 2014 Differential gene susceptibility to sperm DNA damage: analysis of developmental key genes in trout. PLOS ONE 9 e114161. (doi:10.1371/ journal.pone.0114161)

Hamatani T, Falco G, Carter MG, Akutsu H, Stagg CA, Sharov AA, Dudekula DB, VanBuren V \& Ko MS 2004 Age-associated alteration of gene expression patterns in mouse oocytes. Human Molecular Genetics 13 2263-2278. (doi:10.1093/hmg/ddh241)

Han L, Hu Z, Liu Y, Wang X, Hopkins KM, Lieberman HB \& Hang H 2010 Mouse Rad1 deletion enhances susceptibility for skin tumor development. Molecular Cancer 9 67-4598-9-67. (doi:10.1186/14764598-9-67)

Harrouk W, Codrington A, Vinson R, Robaire B \& Hales BF 2000 Paternal exposure to cyclophosphamide induces DNA damage and alters the expression of DNA repair genes in the rat preimplantation embryo. Mutation Research 461 229-241. (doi:10.1016/S09218777(00)00053-7)

Jaroudi S, Kakourou G, Cawood S, Doshi A, Ranieri DM, Serhal P, Harper JC \& SenGupta SB 2009 Expression profiling of DNA repair genes in human oocytes and blastocysts using microarrays. Human Reproduction 24 2649-2655. (doi:10.1093/humrep/dep224)

Khair L, Chang YT, Subramanian L, Russell P \& Nakamura TM 2010 Roles of the checkpoint sensor clamp Rad9-Rad1-Hus1 (911)-complex and the clamp loaders Rad17-RFC and Ctf18-RFC in Schizosaccharomyces pombe telomere maintenance. Cell Cycle 9 2237-2248. (doi:10.4161/ CC.9.11.11920)

Kim B-M, Rhee J-S, Lee K-W, Kim M-J, Shin K-H, Lee S-J, Lee Y-M \& Lee J-S 2015 UV-B radiation-induced oxidative stress and p38 signaling pathway involvement in the benthic copepod Tigriopus japonicus. Comparative Biochemistry and Physiology Part C: Toxicology \& Pharmacology 167 15-23. (doi:10.1016/j.cbpc.2014.08.003)

Kopeika J, Kopeika E, Zhang T, Rawson DM \& Holt WV 2004 Effect of DNA repair inhibitor (3-aminobenzamide) on genetic stability of loach (Misgurnus fossilis) embryos derived from cryopreserved sperm. Theriogenology 61 1661-1673. (doi:10.1016/ j.theriogenology.2003.09.010)

Kurus M, Karakaya C, Karalok MH, To G \& Johnson J 2013 The control of oocyte survival by intrinsic and extrinsic factors. Advances in Experimental Medicine and Biology 761 7-18. (doi:10.1007/978-14614-8214-7)

Lahnsteiner F \& Leitner S 2013 Effect of Temperature on gametogenesis and gamete quality in brown trout, Salmo trutta. Journal of Experimental Zoology Part A: Ecological Genetics and Physiology 319 138-148. (doi:10.1002/jez.1779)
Lin F \& Dabrowski K 1998 Androgenesis and homozygous gynogenesis in muskellunge (Esox masquinongy): evaluation using flow cytometry. Molecular Reproduction and Development 49 10-18.

Liu M, Tee C, Zeng F, Sherry JP, Dixon B, Bols NC \& Duncker BP 2011 Characterization of p53 expression in rainbow trout. Comparative Biochemistry and Physiology Part C: Toxicology \& Pharmacology 154 326-332. (doi:10.1016/j.cbpc.2011.06.018)

Livak KJ \& Schmittgen TD 2001 Analysis of relative gene expression data using real-time quantitative PCR and the 2(-Delta Delta C(T)) Method. Methods 25 402-408. (doi:10.1006/meth.2001.1262)

Marchetti F, Bishop J, Gingerich J \& Wyrobek AJ 2015 Meiotic interstrand DNA damage escapes paternal repair and causes chromosomal aberrations in the zygote by maternal misrepair. Scientific Reports $\mathbf{5}$ 7689. (doi:10.1038/srep07689)

Menezo Y, Dale B \& Cohen M 2010 DNA damage and repair in human oocytes and embryos: a review. Zygote 18 357-365. (doi:10.1017/ S0967199410000286)

Migaud H, Bell G, Cabrita E, McAndrew B, Davie A, Bobe J, Herráez MP \& Carrillo C 2013 Gamete quality and broodstock management in temperate fish. Reviews in Aquaculture 5 S194-S223. (doi:10.1111/ raq.12025)

Perez-Cerezales S, Martinez-Paramo S, Cabrita E, Martinez-Pastor F, de Paz P \& Herraez MP 2009 Evaluation of oxidative DNA damage promoted by storage in sperm from sex-reversed rainbow trout. Theriogenology $\mathbf{7 1}$ 605-613. (doi:10.1016/j.theriogenology.2008.09.057)

Perez-Cerezales S, Martinez-Paramo S, Beirao J \& Herraez MP 2010a Evaluation of DNA damage as a quality marker for rainbow trout sperm cryopreservation and use of LDL as cryoprotectant. Theriogenology 74 282-289. (doi:10.1016/j.theriogenology.2010.02.012)

Perez-Cerezales S, Martinez-Paramo S, Beirao J \& Herraez MP 2010 b Fertilization capacity with rainbow trout DNA-damaged sperm and embryo developmental success. Reproduction 139 989-997. (doi:10.1530/REP-10-0037)

Perez-Cerezales S, Gutierrez-Adan A, Martinez-Paramo S, Beirao J \& Herraez MP 2011 Altered gene transcription and telomere length in trout embryo and larvae obtained with DNA cryodamaged sperm. Theriogenology 76 1234-1245. (doi:10.1016/j.theriogenology.2011. 05.028)

Puebla-Osorio N, Lacey DB, Alt FW \& Zhu C 2006 Early embryonic lethality due to targeted inactivation of DNA ligase III. Molecular and Cellular Biology 26 3935-3941. (doi:10.1128/MCB.26.10.3935-3941.2006)

Rothfuss O, Gasser T \& Patenge N 2010 Analysis of differential DNA damage in the mitochondrial genome employing a semi-long run realtime PCR approach. Nucleic Acids Research 38 e24. (doi:10.1093/nar/ gkp1082)

Santos R, Palos-Ladeiro M, Besnard A, Reggio J, Vulliet E, Porcher JM, Bony S, Sanchez W \& Devaux A 2013 Parental exposure to methyl methane sulfonate of three-spined stickleback: contribution of DNA damage in male and female germ cells to further development impairment in progeny. Ecotoxicology 22 815-824. (doi:10.1007/ s10646-013-1088-3)

Schulte RT, Ohl DA, Sigman M \& Smith GD 2010 Sperm DNA damage in male infertility: etiologies, assays, and outcomes. Journal of Assisted Reproduction and Genetics 27 3-12. (doi:10.1007/s10815-009-9359-x)

Shamsi MB, Imam SN \& Dada R 2011 Sperm DNA integrity assays: diagnostic and prognostic challenges and implications in management of infertility. Journal of Assisted Reproduction and Genetics 28 1073-1085. (doi:10.1007/s10815-011-9631-8)

Speyer BE, Pizzey AR, Ranieri M, Joshi R, Delhanty JD \& Serhal P 2010 Fall in implantation rates following ICSI with sperm with high DNA fragmentation. Human Reproduction 25 1609-1618. (doi:10.1093/ humrep/deq116)

Storer NY \& Zon LI 2010 Zebrafish models of p53 functions. Cold Spring Harbor Perspectives in Biology 2 a001123.

Stout GJ \& Blasco MA 2013 Telomere length and telomerase activity impact the UV sensitivity syndrome xeroderma pigmentosum C. Cancer Research 73 1844-1854. (doi:10.1158/0008-5472.CAN-12-3125)

Takata H, Hanafusa T, Mori T, Shimura M, lida Y, Ishikawa K, Yoshikawa K, Yoshikawa Y \& Maeshima K 2013 Chromatin compaction protects genomic DNA from radiation damage. PLOS ONE 8 e75622. (doi:10.1371/journal.pone.0075622) 
Tchernov D, Kvitt H, Haramaty L, Bibby TS, Gorbunov MY, Rosenfeld H \& Falkowski PG 2011 Apoptosis and the selective survival of host animals following thermal bleaching in zooxanthellate corals. PNAS $\mathbf{1 0 8}$ 9905-9909. (doi:10.1073/pnas.1106924108)

Upadhya D, Kalthur G, Kumar P, Rao BS \& Adiga SK 2010 Association between the extent of DNA damage in the spermatozoa, fertilization and developmental competence in preimplantation stage embryos. Journal of the Turkish German Gynecological Association 11 182-186. (doi:10.5152/jtgga)

Vernier JM 1969 Chronological table of the embryonic development of rainbow trout, Salmo gairdneri Rich. 1836 (Fisheries and Marine Service translation series). Annales d'Embryologie et de Morphogenese 2 495-520.

Wu D, Chen L, Sun Q, Wu X, Jia S \& Meng A 2014 Uracil-DNA glycosylase is involved in DNA demethylation and required for embryonic development in the zebrafish embryo. Journal of Biological Chemistry 289 15463-15473. (doi:10.1074/jbc.M114.561019)

Zan-Bar T, Bartoov B, Segal R, Yehuda R, Lavi R, Lubart R \& Avtalion RR 2005 Influence of visible light and ultraviolet irradiation on motility and fertility of mammalian and fish sperm. Photomedicine and Laser Surgery 23 549-555. (doi:10.1089/pho.2005.23.549)

Received 22 September 2015

First decision 5 November 2015

Revised manuscript received 15 February 2016

Accepted 12 April 2016 